\title{
Impact of climate change on the endangered Nubian dragon tree (Dracaena ombet) in the South Eastern of Egypt
}

\author{
Sayed K. Elnoby ${ }^{1}$ and Abdel Raouf A. Moustafa ${ }^{2} *$ \\ ${ }^{1}$ Ashtum El Gamil Protected Area, Port Said, Egypt \\ ${ }^{2}$ Botany Department, Faculty of Science, Suez Canal University, Ismailia, Egypt
}

\begin{abstract}
This review aims to focus on the Nubian dragon tree, which is a distinctive mark of the Gabal Elba area and is native to that part of Egypt. The dragon trees grow slowly, long-lived, umbrella-shaped, with sword-shaped leaves and found in the semi-desert area, where they grow on inaccessible slopes. The average precipitation on the Gabal Elba area, where the Nubian dragon trees are found is not more than 50 millimeters per year, but the unique location of the mountain in front of the Red Sea and its height about $1435 \mathrm{~m}$, captures water vapour and thus increase the precipitation rate to 400 millimeters per year. The Nubian dragon trees are threatened due to the change of their habitat, over-grazing, the diseases and harmful insects; however, the main factor influencing the Nubian dragon tree is the extreme drought. From total 1450 trees recorded only 870 trees have survived while 580 trees were dead, which represents about $60 \%$ survival and mortality about $40 \%$. The Nubian dragon trees have aesthetic, medicinal, as well as commercial values. One trail succeeded in propagating of Dracaena ombet. The target species was recorded to be endangered and consequently, a plan of conservation should be prepared, fortunately, all the individuals of the population are located inside the Gabel Elba as a protected area, which helps managing the population. Moreover, plant propagation trials should be considered as well as establishing gene bank, conserving its genetic resources. Eventually Dracaena ombet is a unique medicinal plant that needs to be preserved in these natural habitats.
\end{abstract}

Keywords Red Sea, Protected Area, Gabal Elba, native species, conservation.

\section{INTRODUCTION}

Plants are the most important environmental constituent that are considered to be the lungs of the Earth, they play a key role in maintaining the ecosystems in a healthy state, providing basic habitats and food sources for living organisms, protecting land from desertification and soil erosion. Plants are source of cultural heritage (CBD, 2011). The benefits and importance of plants to any part of the Earth cannot be counted because of the many direct and indirect benefits that a vegetation cover can provide, it is easy to see or touch some of the benefits directly, but it is difficult to note the large benefits which takes years to learn its importance in our lives, which is subsequently the lives of our generations. The conservation of wild plants is urgent due to the depletion of the wild plants, which results from over-exploitation, cutting, overgrazing, disease and severe drought, which in turn changed the habitat and decreased the number of the population.

Dracaena is a genus of about 60 species (Mabberley, 1990) of trees and succulent shrubs, most of the species are native to Africa, a few in southern Asia, northern Australia and one species in Central America. D. americana, D. arborea, D. cinnabari, D. draco, D. ombet, and $D$. tamaranae are called dragon trees, they are tree-sized with stout trunks and broad-based leaves. The remaining species are smaller and shrub-like. Generally, investigation the ecology of Dracaena genus plays an important role in the habitat ecology as indicator of habitat quality. The target species which found in Gabal Elba in the south eastern of Egypt is the Nubian dragon tree or Dracaena ombet that became endangered due to the climate change and severe drought. Gebel Elba area is one of the distinct phyto-geographical territories of Egypt (Friis, 1998; El-Hadidi, 2000). No publications deal in-specific with the habitats of Gabel Elba area, some publications focused on the general views and descriptions for this area, Schweinfurth (1865), Anderson (1898), Hoogstraal et al. (1957) and Baha Eldin (2002). Kassas (1957) reported a detailed description for the ecology of Red Sea coastal habitats. Kassas and Zahran (1971) provided a comprehensive description of the region's Ecology. Goodman (1985) and Baha El Din (1997) provided a general summary of the region's habitats, including the main habitats of Dracaena ombet.

The Gabal Elba was declared a protected area by Prime Ministerial Decree 450 for 1986 in order to conserve the biological diversity in this unique region, it lies between latitude $22^{\circ} 0^{\prime}$ to $23^{\circ} 2^{\prime} \mathrm{N}$, longitude $36^{\circ} 0^{\prime}$ to $36^{\circ} 55^{\prime} \mathrm{E}$ at the south-eastern corner of Egypt, The Gabal Elba Protected Area, encompass a cluster of coastal mountains overlooking the Red Sea, immediately to the North of the borders with Sudan, it consists of four main mountains: Gabal Elba $(1,435 \mathrm{~m})$, Gabal Shellal $(1,409 \mathrm{~m})$, Gabal Shendib $(1,911 \mathrm{~m})$ and Gabal Shendodai (1,526m) (Fig. 1). The Gabal Elba is facing the eastern coast of the Red Sea and in front of the currents of the air and clouds which are loaded with

*Corresponding author: raoufmoustafa2@hotmail.com 
moisture. Generally, the Gabal Elba Protected Area contains large plant diversity about 458 plant species forming a green oasis over the slopes of the mountains where they grow, these species are annual or permanent plants representing almost $25 \%$ of the plant species recorded in Egypt (Zahran and Willis 1992). The target species or Dracaena ombet is located on the cliffs of the mountains where the favourable habitats, which are characterized by high humidity. Dragon trees are the distinctive marks of the Gabal Elba area and hardly can exist in any other region in Egypt. We review the taxonomic status, morphology, ecology, uses, main threats, size and distribution of the population, propagation and suggesting a conservation program for this plant.

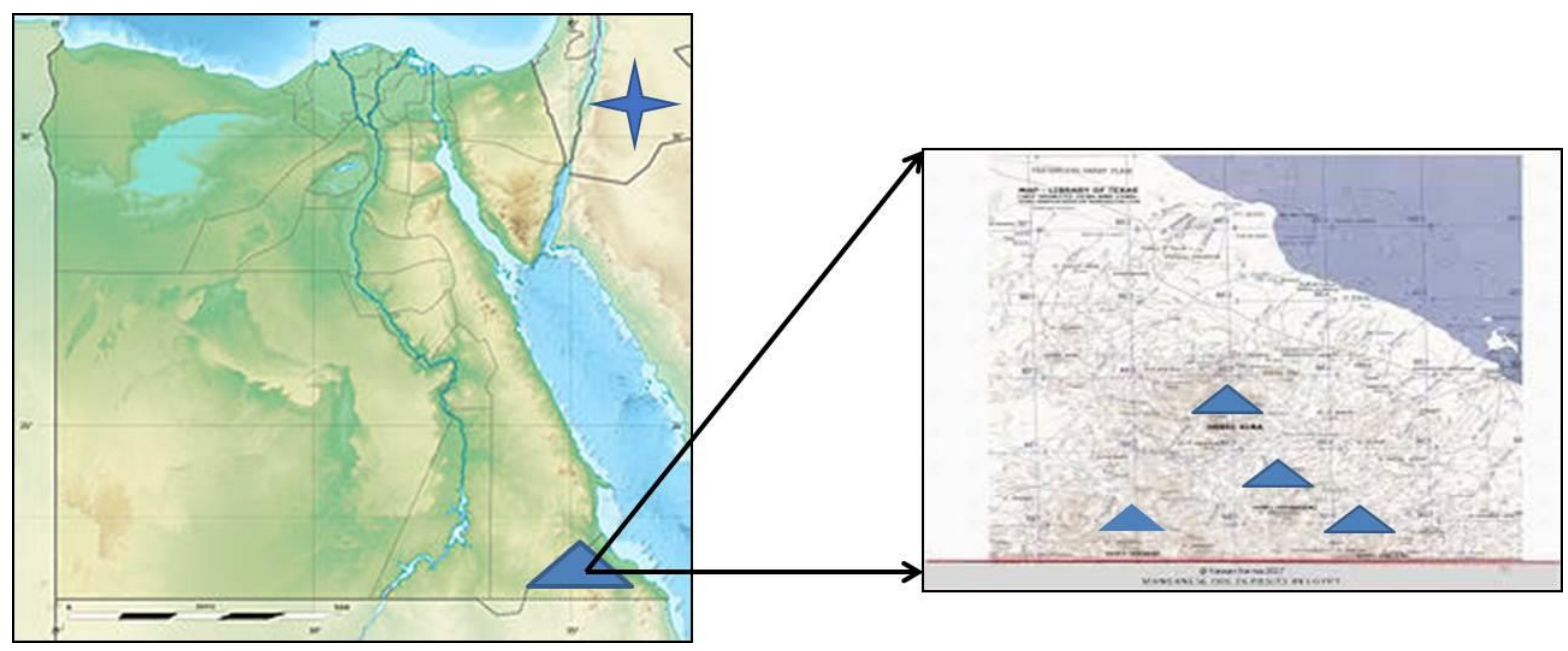

Figure (1): Location map, showing the study area and the main habitats of Dracaena ombet with blue triangles.

\section{Scientific classification}

Kingdom: Plantae

Phylum: Tracheophyta

Class: Liliopsida

Order: Asparagales

Family: Asparagaceae

Genus: Dracaena

Scientific Name: Dracaena ombet (Kotschy and Peyritsch, 1867) (accepted name).

Common Name: Nubian dragon tree

\section{Morphological Description}

Dracaena ombet tree grows slowly, a long-lived, its height is about five meters and has a unique appearance, with a densely packed crown umbrella-shaped. The trunk is forked, smooth, gray in colour, and divided into a number of branches (Fig. 2), with sword-shaped leaves, straight, about one meter long, five centimetres wide, and found only at the end of the youngest branches.

The flowers are white or light pink and have a bright, light fragrance and they bloom in the last spring. The fruits are small one centimetre in diameter, spherical shape fleshy berries containing one small seed, five millimetres in diameter, and during their maturation they turning from green to orange (Kotschy and Peyritsch, 1867).

\section{Foliar micromorphology}

Scanning electron microscopy showed that the leaves are characterized by anomocytic stomata, have no trichomes, and amphistomatic. Stomata are surrounded by a cuticular flange, thick cuticle with a wax layer and a high density of stomata on both sides (Klimko et al., 2008) (Fig. 4).

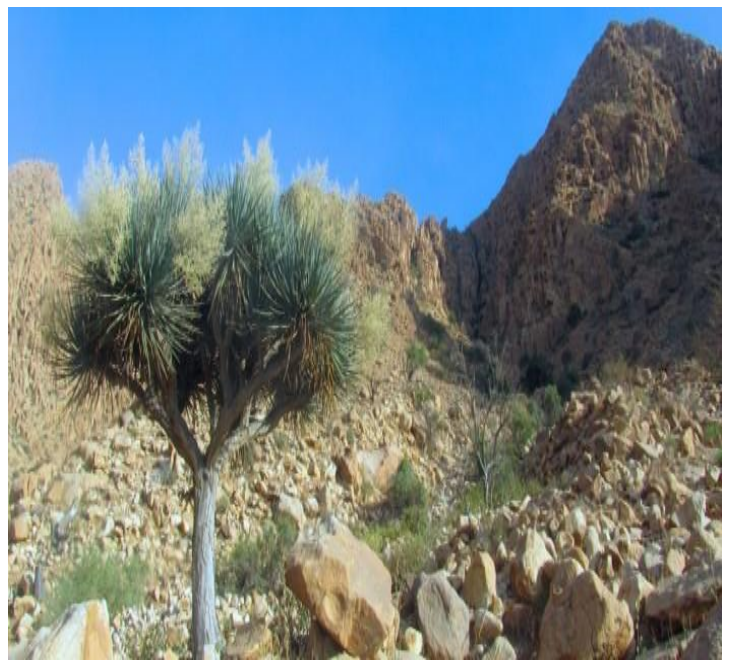

Figure (2): Dracaena ombet (Ghazali et al., 2008)

\section{Folk medicine}

Based on the interviews with local Bedouins in Gebel Elba, one can say Dracaena is substantial economic plant, with a tremendous uses in the traditional medicine. Local Bedouins use D. ombet stems for stomach pains, wounds treatments and leaves parts uses for hair elongation. The $D$. ombet stem scratching to collect an exudation liquid which have viscous feel known as 'el saber', then this exudation taken and but on the wounds 
areas for some days. It also used internally for chest pains, post-partum bleeding, internal traumas and menstrual irregularities. Resin collected from the trunk is used in traditional medicine especially in magic for: inner power, strength, will power, manifesting changes, love spells, exorcism, binding spells, protection, selfdefence, energy, dragon magic, potency, empowering amulets, talismans, or spells, male sex magic, yang energy, consecrating tools, courage, animal magic, purification, cleansing, luck and money spells.

\section{Dracaena ombet as animal fodder}

In most of ecological habitats of Gebel Elba Protected Area Bedouins are used to collect the $D$. ombet tree raw fruits/seeds for their camels. That is due to its edible fruits which are very rich and offer energy. On other hand its fruits have a high protein content and it is reported that it's provide a good food source for local community during the fruiting seasons and for some wild animals such as hyrax and Nubian ibex. Besides, raw seeds are very healthy for camels, especially it have good water content.

\section{Geographical distribution and ecology}

Nubian dragon trees are distributed in Egypt, Djibouti, Eritrea, Ethiopia, Saudi Arabia, Somalia and Sudan (Fig. 3). These trees occur in the semi-desert humid area, where they grow on inaccessible slopes and cliffs with high elevation 450-1450 m, and composed of the basement and transition stones.

These trees can tolerate drought due to their ability to retain water for many years, the strange appearance is an adaptation for survival in these conditions, its crown is umbrella-shaped and the leaves have wax to decrease evaporation, the seeds have a long time of dormancy and are often spread by the wild birds such as the crow (Kotschy and Peyritsch, 1867).

The average annual rainfall on Gabal Elba area is not more than 50 millimeters per year, but the location of the mountain in front of the Red Sea, it capture the mist and thus increase the precipitation rate to 400 millimeters, the mean maximum temperature is $38^{\circ} \mathrm{C}$, the mean minimum temperature $14^{\circ} \mathrm{C}$ and the relative humidity is up to $60 \%$ (www.world climate.com). One trail succeeded in propagating of Dracaena ombet has been done by El Azzouni (2003)

\section{Climate of Gebel Elba}

Based on the Köppen-Geiger Climate Classification System, Gebel Elba is located in a BWh region. Therefore, the national parks considered arid climate, with desert like precipitation and very hot temperatures. Generally, the drought of this region increases markedly from the northeast to the southwest. Air surrounding the locality warms and inclines adiabatically, obstructing condensation and subsequent in extremely tiny amounts of precipitation year round. Besides, Gebel Elba Nat- ional Park practises year round clear skies hence foremost to the sun space heating the land surface of present location strongly and possession the air temperatures relatively high. While temperature is higher the high sun summer months and be likely to cool in the low sun winter months with temperatures over $30^{\circ} \mathrm{C}$ year round.

The dominant winds in Gebel Elba come from southeast (Abu Al-Izz, 1971), from the direction of the sea, therefore more or less frequently, mist over and clouds soak the mountain, giving Gebel Elba a higher biodiversity than any other area of Egypt. The amount of average rainfall is high at $50 \mathrm{~mm}$ in contrast to the other areas from the similar latitude. The precipitation drained from the moisture tapped from clouds and the sea rise the level to $400 \mathrm{~mm}$, revolving Gelbal Elba to be one of the highest amounts of precipitation in Egypt. Anywhere moisture is brought from the sea by the east winds and infuses the mountain, and that increases the cover of vegetation, fauna of the area and makes it the richest area in the whole country. In the meantime, the vegetation percentage decrease considerably on the west and south west slopes of the main habitats of the mountain which are sheltered from the wind and thus receive considerably less dew than the eastern side of the massif.

As stated by Abdel-Ghani and Abdelkhalik (2006), the climate of the study area appears to occupy an intermediate position between those of the regions of the tropical rains and those of the dry Egyptian rocky deserts with their occasional precipitation in winter months. Generally, the climate of the area described by Ayyad and Ghabbour (1986), as arid climate which characterised by spring rainfall ranges between 50 and $10 \mathrm{~mm}$ year- 1 , mild winters $\left(18-22{ }^{\circ} \mathrm{C}\right)$ and hot summers $\left(28-33^{\circ} \mathrm{C}\right)$.

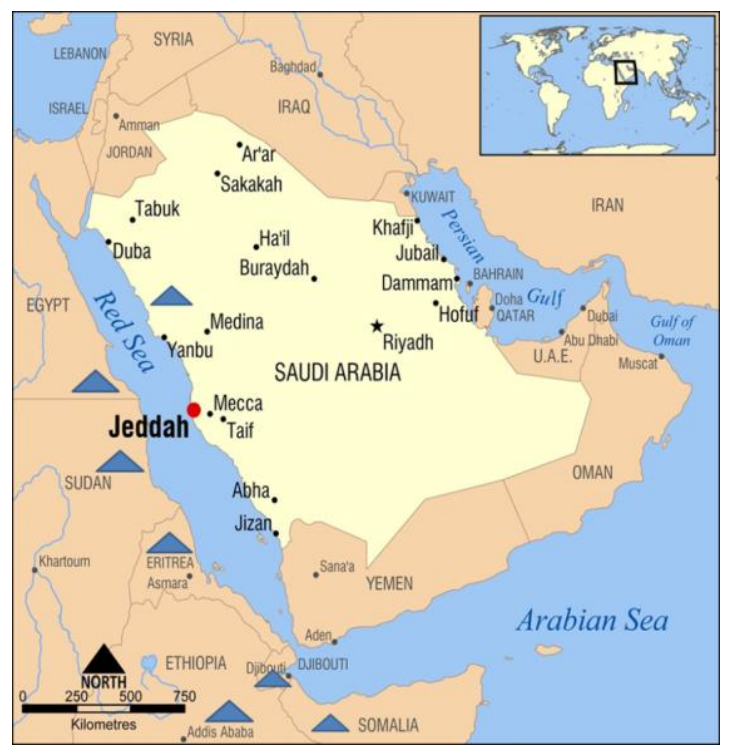

Figure (3): Distribution map, showing the occurrence of the target species with blue triangles 


\section{Threats}

We review the most important threats to Dracaena ombet in Egypt, it is classified as endangered by the International Union for the Conservation of Nature (IUCN, 2006), these plants live in remote parts of Gabal Elba area, that are hard to reach.

They are threatened by the destruction of their habitat, the collection, illegal cutting of trees or their parts, over-grazing of seeds and small seedlings, diseases and harmful insects, but the main factor influencing Dracaena ombet is the extreme drought with also long dormancy (El Azzouni, 2003). In northern Sudan it appears that the populations of the Dracaena ombet have vanished from Erkwit except a few numbers about 63 small trees (based on a personal contact with Ghazali (2017).

Epidemic fungal infections will lead to the near disappearance of Dracaena ombet, nine fungal species were isolated from leaf spots and the most common species were Cladosporium dracaenatum, Alternaria alternata, Aspergillus niger, Curvularia sp., and Fusarium moniliforme, while the less frequency species were Botrytis cinerea, Helminthosporium sp., Fusarium oxysporum and Epicoccum nigrum. Scanning and transmission electron microscopy made by Baka and Krazywinski (1996), it showed the colonization of the pathogens in leaf tissues of Dracaena ombet, and ultrastructural changes were observed in mitochondria, chloroplasts and microorganisms of plant-infected cells.

In Egypt the populations of Dracaena ombet have been discovered near the Sudanese border and most of the mature trees seem unhealthy, due to either as a result of the drought conditions or an attack by parasitic pests, pathogens or diseases (El Azzouni, 2003). Thus we propose that a further studies and investigation of plant diseases, especially pests and fungi. Consequently, the treatment of the Dracaena ombet population should be on both sides of the Egyptian - Sudanese border because the presence of an infected group can cause a serious problem to the other by wind or by human activities, thus we must treat the two groups as a whole population.

\section{Populations size and distribution}

The only detailed study on population of Dracaena ombet done by Ghazali et al. (2008), they have surveyed nine sites in Gebel Elba area, 950 trees represented the largest population of Dracaena ombet were assigned to Camerba mountain site followed by Wadi Aritri and Wadi Tawella of 148 and 100 trees respectively.

The lowest density was recorded in Wadi Aedieb hills of only five trees, other than that most investigated sites had medium to low population densities of Dracaena ombet, the following table shows the population size of Dracaena ombet in their natural habitats (Table 1).

\section{Survival status}

From total 1450 trees recorded about 870 trees observed survived against 580 dead trees, which represent about $60 \%$ survival percent and $40 \%$ dead trees from that total detected population size (Fig. 4).

Most of the trees of the D.ombet populations are old, mature and a bad age structure, they have a diameter trunk $70 \mathrm{~cm}$, height of two meters and there are no new seedlings except a small number, only (8) seedlings are found in Camerba mountain, they were $(0.1-1$ meter $)$ and (2) seedlings are found in W. Ghway, they were (0.4 - 1 meter) (Ghazali et al., 2008).

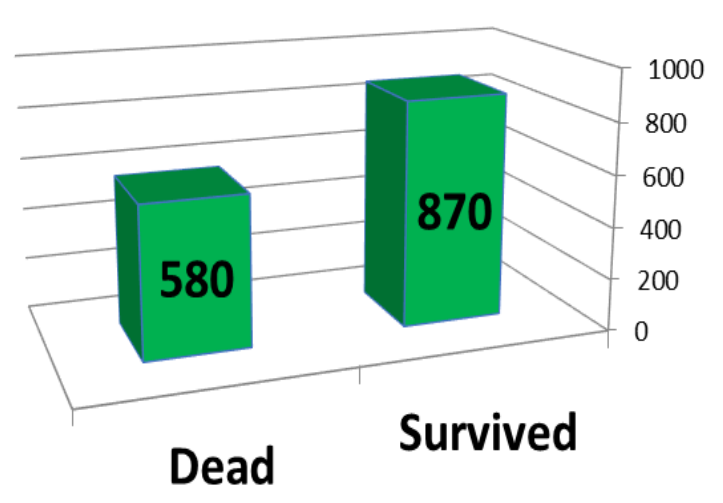

Figure (4): Chart shows the percentage of the survived and dead trees.

\section{The uses}

Dracaena ombet, is known to mankind since ancient times, it has aesthetic, medical, and commercial values, and from its stem a red liquid or sap is extracted and is called resin that used in advanced medical and industrial techniques. This liquid is used to sterilize the wounds and treat the gum ulcers; it helps to stop the bleeding and has commercial uses. The leaves are used to make the finest types of ropes and the trunk is used to make the best types of hives, which contributed to the extinction of the tree (Kotschy and Peyritsch, 1867).

\section{Pharmacological uses}

Not too many publications have been done on the pharmacological effect of Dracaena ombet. Only one main study has been done by Moharram and ElShenawy (2007) where they focused on the pharmacological actions of Dracaena ombet. Two new steroidal saponins, together with six known constituents which isolated from the leaves of Dracaena ombet. The two saponins showed significant anti-inflammatory and analgesic activities.

\section{DISCUSSION}

This review explained that Dracaena ombet is a native species for Gabal Elba and grows on the mountainous cliffs that are difficult to enter by human and has a great economic and medical importance. 
In recent years, the plants population has fallen to a small number and the percentage of dead plants reached about $40 \%$ due to the difficulty of the natural propagation and facing the plants to many of the threatened factors, such as climate change, which led to the lack of rainfall and extreme drought, beside overgrazing, which eliminates the seeds and small seedlings, diseases and pests that infect many seeds and adult plants (Ghazaly, 2005).

According to the IUCN criteria this plant is Endangered (IUCN 1998). A widespread and abundant species known as the Nubian dragon tree, it has experienced population declines throughout its range. Scattered individuals remain in inaccessible areas. The sub- populations on the Red Sea Hills and Jebel Elba in Sudan and Egypt are particularly threatened. Other smaller subpopulations have been discovered in recent years in south-eastern Egypt near the Sudanese border at Gebel Shindeeb, and it may also occur on Gebel Shinodai (El Azzouni, 2003).

As mentioned by Ghazaly (2008) in his study and interviews with local Bedouins of Bisharia tribes' climatic conditions are seen as the main factors which affect the current status of the Dracaena ombet in GE. The effect of climate change appears in the form of reduction in amount of precipitation received by GE. The area has not received any rainfall since 1996 except slight rain in November 2002.

Table (1): The natural habitats of Dracaena ombet and its population size.

\begin{tabular}{ccccc}
\hline \hline No. & Area & Population size & Latitude & Longitude \\
\hline $\mathbf{1}$ & W. Ghway & 30 & $22^{\circ} 12^{\prime} 20.49$ & $36^{\circ} 19^{\prime} 42.58$ \\
$\mathbf{2}$ & W. Darawina-Tewoet & 17 & $22^{\circ} 13^{\prime} 22.73$ & $36^{\circ} 20^{\prime} 40.81$ \\
$\mathbf{3}$ & W. Tawella & $(100)$ & $22^{\circ} 13^{\prime} 19.30$ & $36^{\circ} 22^{\prime} 16.80$ \\
$\mathbf{4}$ & W. Aedieb-Kosheit & 12 & $22^{\circ} 11^{\prime} 51.60$ & $36^{\circ} 21^{\prime} 38.10$ \\
$\mathbf{5}$ & W. Aretri & 148 & $22^{\circ} 12^{\prime} 56.20$ & $36^{\circ} 20^{\prime} 10.40$ \\
$\mathbf{6}$ & W. Akaw & 10 & $22^{\circ} 13 ' 23.34$ & $36^{\circ} 21^{\prime} 21.07$ \\
$\mathbf{7}$ & W. Ashtet & 29 & $22^{\circ} 13^{\prime} 9.17$ & $36^{\circ} 20^{\prime} 25.52$ \\
$\mathbf{8}$ & Shendieb Mountain & 15 & $22^{\circ} 3^{\prime} 48.39$ & $36^{\circ} 13^{\prime} 39.39$ \\
$\mathbf{9}$ & W. Aedieb Hills & 5 & $22^{\circ} 11^{\prime} 57.35$ & $36^{\circ} 23^{\prime} 23.10$ \\
$\mathbf{1 0}$ & W. Marafay & 62 & $22^{\circ} 12^{\prime} 26.73$ & $36^{\circ} 20^{\prime} 7.81$ \\
$\mathbf{1 1}$ & Wadi Nahaeeb & 70 & $22^{\circ} 12^{\prime} 8.18$ & $36^{\circ} 19^{\prime} 31.47$ \\
$\mathbf{1 2}$ & Camerba Mountain & 950 & $22^{\circ} 12^{\prime} 8.70$ & $36^{\circ} 19^{\prime} 17.03$ \\
$\mathbf{1 3}$ & Kans-Srob-hills & 1 & - & - \\
& TOTAL & 1450 & & - \\
\hline \hline
\end{tabular}

Therefore, the woodland decline is related in some way to climate change, where this is related to degradation of mountain habitats as a result of the extreme drought conditions and where also there is a shortage of natural resources, effecting local people in the upper zones where Dracaena grows. Subsequently, this leads to overexploitation of natural resources especially fuel wood taken from the various acacia species tree and other species. Resources are limited in the lower zones, in the wades and coastal plains and these areas show more signs of the effect from the drought than other areas.

In the meantime a survey of the Gebel Shindeeb subpopulations had been done by El Azzouni (2003) shows that they comprise only mature plants, many of which appear unhealthy, either as a result of the drought conditions or an attack by a parasitic pest or disease. The infected subpopulations are showing signs of a marked decline and there was no evidence of any young plants (El Azzouni 2003).

In northern Sudan it appears that the populations of D. ombet have completely vanished from Erowit, the only area where they are known to have existed in that country (El Azzouni 2003). The main population of $D$. ombet shows a reduction in the number of individuals with a very high death rate due to impact of climate change in form of drought and deterioration of natural habitat. Many trees died but they died standing on the ground, although they passed several years ago in this case, they stand as a witness and evidence of the events that they passed and led to their death. There is no traces of the human activities such as cutting, except overgrazing, its effect was present but on seeds and small seedlings (Ghazali et al., 2008) but not on the adult trees and there is no traces of the effect of the insects such as secretions, pores, holes and tunnels in the trunks of the trees.

Therefore, one can say that the most important factor was the extreme drought, which led to change the habitats led to the seeds did not find the wet soil so they cannot germinate or they had a weak germination and died later. Subsequently, a conservation and propagation program of the Dracaena omebt is very important and needed. This species requires a great attention and concern about the condition of its population. Fortunately, all the individuals of the population are located inside the Gabel Elba Protected Area, thus we must prepare a management and an action plan, a permanent 
monitoring program, rehabilitation of the plants and their habitat, preparing plant databases, environmental awareness, environmental education for the local community and their participation in the plant conserveation program. Communication and cooperation with scientific research centers, Egyptian and foreign universities, governmental, non-governmental organizations and international agencies that are working in the same field to exchange experiences and providing scientific, technical and financial support. We need further studies, future research and a special approach to deal with the aspects of plant propagation and must be concerted efforts to conserve the biological diversity to be available to humankind and nature.

\section{RECOMMENDATIONS}

Dracaena ombet is a threaten plant which needs an immediate attention, continuous efforts, encourage voluntary work and implementation of the integrated conservation program. Further studies including monitoring and plant propagation, gene bank conservation, as the plant genetic resources, are recommended to preserve our natural heritage alive.

\section{ACKNOWLEDGMENTS}

The author wishes to express his thanks to Usama Mohammed Ghazali, a senior ranger of the Gabel Elba protected area for his help and provided many constructive comments to complete this the manuscript.

\section{REFERENCES}

ABD EL-GHANI, M.M., AND K.N. ABDEL-KHALIK. 2006. Floristic diversity and hytogeography of the Gebel Elba National Park، South-East Egypt. Turkish Journal of Botany 30: 121-136.

ABU AL-IZZ M.S. 1971. Landforms of Egypt. Cairo: The American University in Cairo Press.

ANDERSON, J. 1898. Zoology of Egypt. I, Reptilia and Batrachia. B. Quatrich, London.

AYYAD, M.A., AND S.I. GHABBOUR. 1986. Hot deserts of Egypt and the Sudan. In: Evenari $M$ et al. (eds.) Ecosystems of the World 12B, Hot Deserts and Arid Shrublands, pp. 149-202. Amsterdam: Elsevier.

BAHA EL DIN, S.M. 1997. Report on the rapid field assessment of the Elba Protected Area. May 1997, Report for NCS, EEAA

BAHA EL DIN, S.M. 2002. Biodiversity assessment in the Elba Protected Area, with implications for Management, Report for NCS, EEAA and EIECP.

BAKA, Z.A.M. AND K. KRAZYWINSKI. 1996. Fungi associated with leaf spots of Dracaena ombet (Kotschy and Peyr). Microbiological Research 151: 49-56.

CBD. 2011. Convention on Biological Diversity. Global Strategy for Plant Conservation: 2011-2020. Richmond.
D.F. Culter (eds.), Chorology, Taxonomy and Ecology of the Floras of Africa and Madagascar, pp:25-51. Royal Botanic Gardens, Kew-UK.

EL AZZOUNI, M. 2003. Conserving Dracaena ombet, Egypt's Dragon Tree. Plant Talk 34: 38-39.

EL-HADIDI, M.N. 2000. Flora Aegyptiaca, Vol. 1. The Palm Press and Cairo University Herbarium, Cairo, Egypt.

EL-SHENAWY S.M., F.A. MOHARRAM. 2007. Antinociceptive and anti-inflammatory steroidal saponins from Dracaena ombet. Planta Med; 73(10):1101-6.

EL-SHENAWY SM, MOHARRAM FA. 2007. Antinociceptive and anti-inflammatory steroidal saponins from Dracaena ombet. Planta Med; 73(10):1101-6.

FRIIS, I. 1998. Frank White and development of African chorology. In: Huxley, C.R., J.M. Lock and D.F. Culter (editors). Chorology, taxanomy and Ecology of the Floras of Africa and Madagascar.Pp. 25-51. Royal Botanic Gardens, Kew

GHAZALI, U., H. EL BAILY AND A. DORA. 2008. The globally endangered Dracaena ombet monitoring and assessment project in Gabel Elba protected area, Egypt. Final Report, Conservation Leadership Programme.

GHAZALI. 2017. based on a personal contact with Ghazali 2017.

GHAZALY, U. 2005. A report on assessment of the Dracaena omebt in GEPA. November 2005, Report for NCS, EEAA.

GHAZALY, U. 2008. When climate change breaks down traditional laws in mountain areas: Case study for the Gabel Elba protected area in Egypt on the effect of climatic change on the endangered Dracaena ombet tree. Mountain Forum.

GOODMAN, S.M. 1985. Natural resources and management considerations, Gebel Elba Conserv-ation Area, Egypt/Sudan. WWF/IUCN Project, No. 3612.

HOOGSTRAAL, H., K.WASSIF AND M.N. KAISER. 1957. Results of the NAMRU-3 southeastern Egypt expedition, 1954. 1. Introduction, itinerary and environmental conditions. Bull. Zool. Soc. Egypt, 13:1-15.

IUCN. 1998 IUCN Red List of Threatened Species. The World Conservation Union. www. iucnredlist.org.

IUCN. 2006. IUCN Red List of Threatened Species. Gland, Switzerland: The World Conservation Union. www.iucnredlist.org.

KASSAS, M. 1957. On the ecology of the Red Sea coastal land. J. Ecol. 45: 187-203.

KASSAS, M. AND ZAHRAN, M. 1971. Plant life on the coastal mountains of the Red Sea, Egypt. J. Indian Bot. Soc. 50a: 571-589.

KLIMKO M. AND J.WILAND SZYMAŃSKA 2008: Scanning electron microscopic studies of leaf surface in taxa of genus Dracaena L. (Dracaen-aceae). Rocz. AR Pozn. 387, Bot. -Stec. 12; 117- 127.

KOTSCHY, AND PEYRITSCH. 1867. Dracaenaceae 
Dracaena ombet Pl. Tinn. 47.

MABBERLEY, D.J. 1990. The Plant-Book. A portable dictionnary of the higher plants. Cambridge: Cambridge University Press.

MOHARRAM, FA, SM.EL-SHENAWY. 2007. Antinociceptive and anti-inflammatory steroidal saponins from Dracaena ombet. Planta Med; 73(10):1101-6.

QASHASH, A. 2006. Plant in the mountains of Sarawat and Hejaz. Medina: Medina Press.

SCHWEINFURTH, G. 1865. Das land am Elba and Soturba Gebirge oder der vom Bischarin tribus
Ammed Goram bewonhte theil des nubischen Kuste. Petrm. Mittheil. 1865: 330-340.

UNESCO. 2006. Report of the Expert Meeting on Desert Landscapes and Oasis Systems< http://whc. unesco. org/archive/2001/whc-01conf208 inf10e. pdf > [18 Nov.2006].

WMC. 1998. Dracaena ombet. In: IUCN 2006 IUCN Red List of Threatened Species. <www. Iucnre dlist. org>. [28 October 2007]. www.world climate.com

ZAHRAN, AND A.J. WILLIS. 1992: The vegetation of Egypt. London.

\section{تأثير تفير المناخ على شجرة التنين النوبي المهادة بالانقراض في الجنوب الشرقي لمصر}

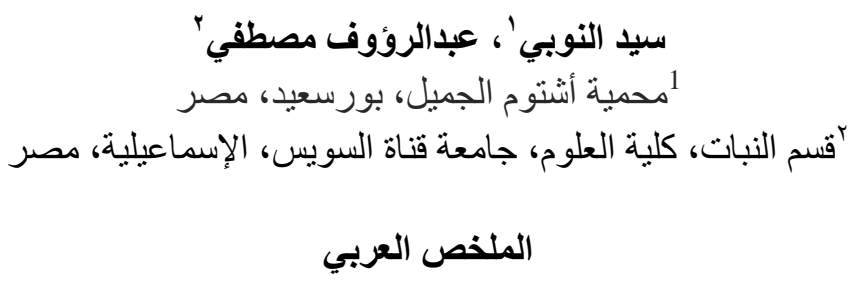

تهدف هذه الدر اسه المرجعية إلى التعرف على شجرة التنين النوبي، اسمها العلمي در اسينا أومبيثDracaena ombet، و التي تنتشر على منحدرات جبل علبة حيث تنمو على منحدرات صعب الوصول إليها. وهذه الاشجار طويلة العمر و تتمو بيطء

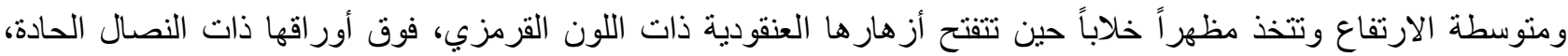
الثبيهة بالسيوف وتوجد فوق قم جبال علبة حيث رطوبة عالية. وهي شجرة خشبية ذات أوراق طويلة لحمية خضر اء يصل طول الثجرة منها من كــ أمتار وشجرة التنين النوبي من العلامات المميزة لمنطقة جبل علبة حيث يختص جبل علبة بتو اجدها دون أي

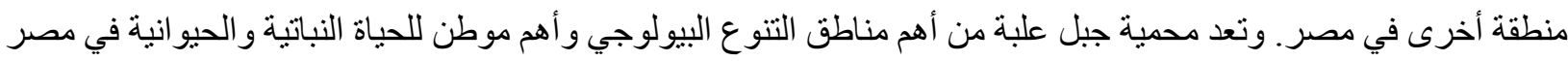
تتميز منطقة جبل علبة بتساقط الأمطار، حيث توجد أشجار التتين النوبي، بمتوسط لا يزيد عن •ـ ملم في السنة، ولكن الموقع الفريد لجبل علبة أمام البحر الأحمر وارتفاعه حوالي هبـ ا م يعمل على التقاط بخار الماء من الجو وبالتالي يؤدي الي زيادة معدل

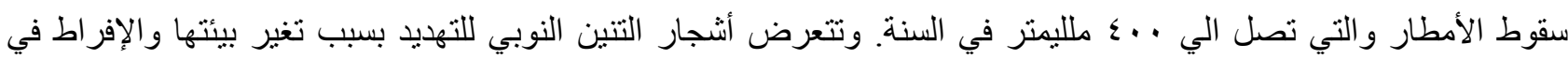
الرعي و الاصابة بالأمر اض الحشرية الضارة ومع ذلك فإن العامل الرئيسي الذي يؤثر على شجرة التنين النوبي هو الجفاف الثديد نتيجة لتغير المناخ في السنوات الاخيرة. وتصل مجموع الاعداد المسجلة لهذه الثجرةالي .0؛ اشجرة. و و تتمتع أشجار التنين النوبي بقيم جمالية وطبية وكذلك تجارية. ومحاو لات اكثار ها لم تتجح وبالتالي اصبحت هذه الثجره مهددة بالانقر اض.لذا يجب إعداد خطة للحفاظ على شجرة التنين النوبي. وكذلك إنشاء بنك للجينات للحفاظ على مو اردها الجينية. كما يجب نشر الوعى البيئي وتضافر الجهود للمحافظه علي هذا النوع من النباتات في بيئته الطبيعية. 